\title{
MUCOLYTIC ENZYME SYSTEMS. X. SERUM HYALURONIDASE INHIBITOR IN LIVER DISEASE ${ }^{1}$
}

\author{
By GEORGE G. SNIVELY AND DAVID GLICK
}

(From the Departments of Internal Medicine and Physiological Chemistry, University of Minnesota Medical School, Minneapolis)

(Submitted for publication February 8, 1950 ; accepted, May 15, 1950)

The hyaluronidase inhibiting property of blood serum has been found to be increased in such diverse clinical states as infectious diseases of bacterial and viral origin $(1-4)$, neoplastic disease $(5,6)$, and the postpartum state in women $(7)$ as well as in several of the so-called "collagen diseases" of unknown etiology, notably rheumatic fever $(8,9)$, disseminated lupus erythematosis (2) and dermatomyositis (2). Intensive studies to determine the anatomical site of origin and to understand better the nature of this substance have been undertaken, and are still under way in this laboratory.

Clear evidence of the site of origin of the inhibiting substance is lacking. Wattenberg and Glick (10), in an analysis of a wide variety of tissues from the rabbit, found it in none of the material studied. In the course of their investigations they noted that certain hemoglobin derivatives and steroids possessed inhibitory properties; extending their observations, they noted that many similar chemical compounds also produced inhibition, but that such compounds were uniformly heat stable and not, as is the serum inhibitor, heat labile. The interest in these investigations, as well as in the current one, has been in the nonspecific inhibitor which will act on the enzyme regardless of its source, rather than the specific antibody inhibitors that develop when hyaluronidase is used as an antigen (11). It has also been found that the inhibitor migrates with albumin in an electrophoretic field $(12,13)$.

This migration with serum albumin, and the finding of an inhibiting property inherent in various products of liver metabolism (10), prompted an evaluation of the serum inhibiting property in disorders of the liver, since it was felt that a de-

1 This work was supported in part by grants from the Division of Research Grants and Fellowships of the $\mathrm{Na}$ tional Institutes of Health, United States Public Health Service, Bethesda, Maryland, and the Medical Research Fund of the Graduate School, University of Minnesota. nominator common to the protean conditions showing increased serum inhibition might be alteration, in greater or lesser degree, of hepatic function. The previously noted lack of evidence of inhibitor in liver tissue (10) was held to be possibly explainable by the premise that the substance might be manufactured in an organ but not stored therein. The current work concerns itself with an attempted correlation between serum inhibitor and the clinical course and laboratory findings in a selected group of patients with liver disease.

\section{MATERIALS AND METHODS}

The technic of the preparation of materials, the viscosimetric assay method, and the method of calculation of results follow the procedure as described by Glick and Gollan (1) and modified by Wattenberg and Glick (10). The hyaluronic acid employed was obtained from human umbilical cords, and the hyaluronidase from bull testes. The assays were carried out on $0.02 \mathrm{ml}$. samples of serum, and when repeated analyses were to be run on the same patient, the material was stored at $-25^{\circ}$ C. until all could be run at the same time, thus eliminating possible variations between different batches of enzyme and substrate. In most instances the patient was used as his own control, via comparisons in serial determinations. The degree of inhibition has been expressed as per cent inhibition, and in a large series of normal humans the mean was found to be $21.5 \pm 0.7$. This range of normal values was found to hold for an age group well beyond that covered by the patients in the group studied in this investigation.

Concomitant determinations were available of routine laboratory studies of blood and urine, and in most instances serial values of erythrocyte sedimentation rate, total and fractional serum protein, serum bilirubin (both one minute and total), cephalin-cholesterol flocculation, thymol turbidity, bromsulfalein retention and urine urobilinogen, serum alkaline phosphatase activity, and cholesterol and cholesterol esters. Routine control sera from normal individuals were run at frequent intervals throughout the entire investigation; these were found to fall within 1 per cent of the previously established normal average value. Serial determinations of inhibitor were made during periods believed to represent changes in the clinical course of the disease process, though in some 
TABLE I

Hyaluronidase inhibition by sera of patients with liver disease

\begin{tabular}{|c|c|c|}
\hline Disease & No. cases & $\begin{array}{c}\text { Mean } \\
\text { per cent } \\
\text { inhibition } \\
\pm \text { std. error } \\
\text { of mean }\end{array}$ \\
\hline \multicolumn{3}{|l|}{ Cirrhosis } \\
\hline With alcoholic history & 21 & $52 \pm 3$ \\
\hline Without alcoholic history & 4 & $40 \pm 5$ \\
\hline \multicolumn{3}{|l|}{ Viral hepatitis } \\
\hline Infectious hepatitis & 8 & $48 \pm 4$ \\
\hline Homologous serum hepatitis & 9 & $43 \pm 3$ \\
\hline Infectious mononucleosis & 5 & $42 \pm 3$ \\
\hline \multicolumn{3}{|l|}{ Miscellaneous } \\
\hline Chronic cholangitis & 1 & 67 \\
\hline Carbon tetrachloride poisoning & 1 & 94 \\
\hline Primary cholangiolitic cirrhosis & 2 & 69 \\
\hline
\end{tabular}

instances routine determinations were done weekly or biweekly.

\section{RESULTS}

The clinical material ${ }^{2}$ consisted of 50 patients with clinical and laboratory evidence of liver disease; these were classified into several groups, and with the mean value of inhibitor taken at the acme of the disease as gauged by laboratory and bedside examination, these are listed in Table I.

Analysis of the data obtained suggested no significant difference between the various types of

2 The clinical material was studied through the courtesy of Dr. C. J. Watson, Head of the Department of Medicine, University of Minnesota, and Dr. R. V. Ebert, Chief of the Medical Service, Veterans Hospital, Minneapolis. liver disease as grouped in Table I; no predictable pattern was found to obtain in any one group that might serve to distinguish it from the other groups of liver disease. There was, however, a rather close correlation of the level of the inhibitor with the clinical course of the disease in all cases observed, in that the highest inhibitor levels were found when the disease process was clinically most severe, with a decline in the level as the disease remitted as gauged by the bedside examination. Similarly, in other papers of this series, a decline from previously high values has been reported in the recovery stage of acute poliomyelitis (1), and in a wide variety of infectious diseases (3). The clinical and laboratory course of a typical case from the material studied is shown in Table II.

An exception to this direct correlation was observed in several cases of hepatic coma, in which as the extreme terminal phase of hepatic failure was reached, distinctly subnormal values obtained; this was found in patients who had shown abnormally elevated values prior to their terminal liver failure.

In the light of the finding by Wattenberg and Glick (10) of an inhibitor effect inherent in several bile constituents, the possibility was entertained that the elevated inhibitor values might be due to an additive effect of these constituents, in cases where the serum levels of bile products were elevated. This was disproved by the finding of a

TABLE II

Clinical and laboratory course of a case of uncomplicated infectious hepatitis, showing relationship to hyaluronidase inhibitor of serum

Days after clinical onset

Subjective symptoms*

Liver tenderness

Liver size in cms. below costal margin

Total serum proteins, gms. per cent

Serum albumin, gms. per cent

Serum globulin, gms. per cent

Cephalin flocculation

Thymol turbidity units

Alkaline phosphatase, $K . A$. units

Serum bilirubin, $1^{\prime}$ value, $m g m$. per cent

Serum bilirubin, total, mgm. per cent

Serum cholesterol, total, mgm. per cent

Cholesterol esters, per cent of total

Bromsulfalein retention, per cent

Prothrombin time, $\frac{\text { patient }}{\text { control }}$ secs.

Urine urobilinogen, Ehrlich units per two hour specimen

Hyaluronidase inhibition, per cent

\begin{tabular}{|c|c|c|c|c|c|}
\hline $\begin{array}{c}8 \\
4+ \\
4+ \\
6 \\
6.9 \\
3.9 \\
3.0 \\
4+ \\
9.7 \\
33 \\
15 \\
26 \\
175 \\
46 \\
38 \\
19.7 \\
14.0 \\
22\end{array}$ & $\begin{array}{c} \\
4+ \\
13.5 \\
19 \\
27\end{array}$ & $\begin{array}{c}19 \\
+ \\
4+ \\
2 \\
7.6 \\
4.4 \\
3.2 \\
4+ \\
9.0 \\
16 \\
3.5 \\
6.0 \\
\\
10 \\
14.0 \\
13.5 \\
5.6\end{array}$ & $\begin{array}{l}3+ \\
7.5 \\
1.5 \\
3.0\end{array}$ & $\begin{array}{c}35 \\
0 \\
0 \\
0 \\
8.0 \\
4.7 \\
3.3 \\
+ \\
4.5 \\
9 \\
0.6 \\
1.3 \\
230 \\
60 \\
1.9 \\
14.0 \\
14.0 \\
0.8\end{array}$ & $\begin{array}{l}0 \\
4.0 \\
0.3 \\
0.7\end{array}$ \\
\hline 53 & 49 & 44 & 40 & 32 & 18 \\
\hline
\end{tabular}

* Subjective symptoms classified according to severity, with $4+$ representing maximum subjective discomfort, and 0 representing the asymptomatic state. 
TABLE III

Correlation of hyaluronidase inhibitor with liver function tests

\begin{tabular}{l|c|c|c}
\hline \multicolumn{1}{c|}{ Measurement } & $\begin{array}{c}\text { No. } \\
\text { determina- } \\
\text { tions }\end{array}$ & $\begin{array}{c}\text { Coefficient } \\
\text { of } \\
\text { correlation }\end{array}$ & (P) \\
\hline Alkaline phosphatase & 40 & 0.88 & $<0.001$ \\
Total cholesterol & 46 & 0.58 & $<0.001$ \\
Bromsulfalein & 44 & 0.54 & $<0.001$ \\
Bilirubin (1') & 58 & 0.78 & $<0.001$ \\
Total protein & 48 & 0.07 & 0.6 \\
Cephalin flocculation & 75 & 0.11 & 0.3 \\
Thymol turbidity & 59 & 0.14 & 0.2 \\
Urinary urobilinogen & 63 & 0.20 & 0.8 \\
Cholesterol ester & 46 & 0.12 & 0.4 \\
\hline
\end{tabular}

complete loss of hyaluronidase inhibition in these sera after heating to $60^{\circ} \mathrm{C}$., indicating that their inhibitory property differed from the heat stable inhibitor of the chemical compounds found in bile.

A calculation of the coefficient of correlation for the hyaluronidase inhibitor in the serum with several of the laboratory tests of liver function is shown in Table III. As indicated by these data, a positive correlation is found with serum alkaline phosphatase, total cholesterol, bilirubin, and bromsulfalein retention. No statistically significant correlation was found with the remainder of the liver function tests followed in this investigation. Further analysis of the data with respect to these four liver function tests showing good correlation was undertaken; no significant difference was noted between the several types of liver disease, particularly between the major divisions of hepatitis and cirrhosis. This finding suggested that the measurement of hyaluronidase inhibition in the sera of patients with liver disease provided a measure of nonspecific liver damage which was in no way unique to a particular type of liver disease.

Of interest was the finding, in several cases of liver disease where the patient could be followed beyond the early convalescent period, that the elevated inhibitor value persisted to a time at which the orthodox tests of liver function had returned to normal ; the possibility that alteration in hyaluronidase inhibitor may be a more sensitive measure of abnormal hepatic function must be considered, although insufficient data are available at present to permit conclusions.

\section{SUMMARY AND CONCLUSIONS}

1. Studies were carried out on the inhibitory effect on hyaluronidase activity of sera from pa- tients with liver disease, and an attempt at correlation of this inhibition with clinical course and with laboratory tests of hepatic function was undertaken.

2. A definite correlation was found between serum hyaluronidase inhibitor and both clinical course and several laboratory tests of liver function, i.e., alkaline phosphatase, bilirubin, bromsulfalein, and total cholesterol. Several other tests showed no significant correlation. Elevated values were noted when the disease process was at its height, and these values diminished as the patients recovered.

3. An exception to this correlation was noted in several cases of severe hepatic coma; here previously elevated values became subnormal in the very terminal stages of hepatic failure. This finding has suggested the interesting speculation that the integrity of a certain amount of hepatic function is necessary for the development of both normal and elevated levels of serum inhibitor.

The authors wish to express their appreciation to Marianne Kaufmann and Page Edmondson for their technical assistance.

\section{BIBLIOGRAPHY}

1. Glick, D., and Gollan, F., Mucolytic enzyme systems. I. Inhibition of hyaluronidase by serum in poliomyelitis. J. Infect. Dis., 1948, 83, 200.

2. Grais, M. L., and Glick, D., Mucolytic enzyme systems. II. Inhibition of hyaluronidase by serum in skin diseases. J. Invest. Dermatol., 1948, 11, 259.

3. Grais, M. L., and Glick, D., Mucolytic enzyme systems. VI. Inhibition of hyaluronidase by serum in infectious diseases. J. Infect. Dis., 1949, 85, 101.

4. Thompson, R. T., and Moses, F. E., Specificity of human serum antihyaluronidase for antagonism of a particular species of bacterial hyaluronidase. Federation Proc., 1948, 7, 282.

5. Hakanson, E. Y., and Glick, D., Mucolytic enzyme systems. III. Inhibition of hyaluronidase by serum in human cancer. J. Nat. Cancer Institute, 1948, 9, 129.

6. Glick, D., Good, T. A., and Bittner, J. J., Mucolytic enzyme systems. IV. Relationship of hyaluronidase inhibition by blood serum to incidence of mammary cancer in mice. Proc. Soc. Exper. Biol. \& Med., 1948, 69, 524.

7. Hakanson, E. Y., and Glick, D., Mucolytic enzyme systems. VIII. Inhibition of hyaluronidase by human blood serum during the normal menstrual 
cycle and pregnancy. J. Clin. Invest., 1949, 28, 713.

8. Good, R. A., and Glick, D., Mucolytic enzyme systems. IX. Non-specific hyaluronidase inhibitor in rheumatic fever. J. Infect. Dis., 1950, 86, 38.

9. Friou, G. J., and Wenner, H. A., On the occurrence in human serum of an inhibitory substance to hyaluronidase produced by a strain of hemolytic streptococcus. J. Infect. Dis., 1947, 80, 185.

10. Wattenberg, L. W., and Glick, D., Mucolytic enzyme systems. VII. Effects of tissue extracts and body fluids, certain steroids and hemoglobin derivatives on hyaluronidase activity. J. Biol. Chem., 1949, 179, 1213.

11. Duran-Reynals, F., Tissue permeability and the spreading factors in infection; contribution to the host: parasite problem. Bact. Rev., 1942, 6, 197.

12. Glick, D., and Moore, D. H., Hyaluronidase inhibitor in electrophoretically separated fractions of human serum. Arch. Biochem., 1948, 19, 173.

13. Moore, D. H., and Harris, T. N., Occurrence of hyaluronidase inhibitors in fractions of electrophoretically separated serum. J. Biol. Chem., 1949, 179, 377. 